\title{
VARIABILITY OF BIOACTIVE PROPERTIES AND ANTIOXIDANT ACTIVITY IN COMMERCIALLY GROWN CHERRY TOMATO (SOLANUM LYCOPERSICUM VAR. CERASIFORME) CULTIVARS GROWN IN INDIA
}

\author{
P.K. Kannaujia ${ }^{a *}$, N. Patel ${ }^{b}$, R. Asrey ${ }^{b}$, M.K. Mahawar ${ }^{a}$, V.S. Meena ${ }^{c}$, B. Bibwe ${ }^{a}$, \\ K. JALGAONKAR ${ }^{\mathrm{a}}$ and N. NEGI ${ }^{\mathrm{c}}$ \\ ${ }^{a}$ Central Institute of Post-Harvest Engineering and Technology, Abohar, Punjab. India \\ ' Indian Agricultural Research Institute, New Delhi. India

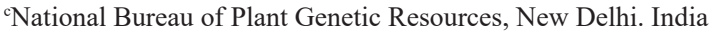

(Received: 23 March 2019; accepted: 19 July 2019)

In this study, six commercial cherry tomato cultivars were analysed for variations in biochemical and technological
parameters. Significant differences were observed among cultivars with respect to their technological and functional
quality attributes. About 2.48 -fold variation in titratable acidity, 2.47 -fold variation in total phenolics, 4.13 -fold
variation in total carotenoid and 7.68 -fold variation in lycopene contents were recorded. The total antioxidant
activity and respiration rate were also found to vary about 1.85 -fold and 1.48 -fold, respectively. The highest
antioxidant activity and total phenolic content were found in the Cherry tomato hybrid no.1 followed by Pusa cherry
tomato-1. Hierarchical cluster analysis revealed that Cherry tomato hybrid no. 1 , Pusa cherry tomato-1, and Nagmoti
cultivars were abundantly rich in phytochemical and bioactive compounds.
Keywords: antioxidant activity, ascorbic acid, hierarchical cluster analysis, total carotenoids, total phenolics

Daily consumption of fruits and vegetables should be increased in the diet as they are important sources of biologically active compounds. Most edible fruits and vegetables supply a balanced combination of bioactive molecules like vitamins $\mathrm{C}$ and $\mathrm{E}$, polyphenols and carotenoids, along with complex carbohydrates and dietary fibre. Dietary consumption of bioactives has several health benefits as well as having anticarcinogenic, anti-mutagenic, and anti-inflammatory molecules (BRUNo et al., 2018). Oxidation is required for the energy production in plants, but overproduction of reactive oxygen species (ROS) damages cells and hampers their normal functions. These ROS attack DNA and proteins, which ultimately cause ageing of cells (APAK et al., 2008). Consumption of dietary antioxidants can detoxify excess ROS and protect the organs against oxidative damage.

In recent years, popularity of cherry tomatoes (Solanum lycopersicum var. cerasiforme) has increased due to the generally higher sugar content and concentrations of many healthpromoting bioactives (antioxidants, carotenoids, ascorbic acid, phenolic compounds, etc.) than conventional tomatoes (BRANDT et al., 2003; LenUCCI et al., 2006; HelYes et al., 2008). Similarly to others, colour of the ripe berries ranges from red to yellow, green, and black due to the introgression of a wide range of spontaneous or induced colour mutations (ILAHY et al., 2019). The fruit are attached to long panicles, and their diameters vary from 1.5 to $3.5 \mathrm{~cm}$.

\footnotetext{
* To whom correspondence should be addressed. Phone: +016342224024; e-mail: pankajkannaujia@ymail.com
} 
Quality components such as size, firmness, colour, taste, and nutritional value are significant for marketing of tomato fruit (ILAHY et al., 2018).

The aim of the present work was to evaluate the variation of health-promoting bioactive compounds among the six cherry tomato cultivars grown inside a polyhouse. The effect of these compounds of selected cultivars in terms of their correlation coefficient was also evaluated and presented.

\section{Materials and methods}

\subsection{Experimental material and treatments}

Cherry tomato cultivars, namely Cherry tomato hybrid no.1, Wild Texas, Pusa cherry tomato-1, Yellow pear, NSL cherry, and Nagmoti were grown inside a polyhouse at the Centre for Protected Cultivation Technology, Indian Agricultural Research Institute (IARI), New Delhi, India. Seedlings were germinated in multi celled plastic plug trays. A well decomposed and sterilized soil-less medium containing cocopeat, vermiculite, and perlite (3:1:1) was used as substrate. 30 -day-old seedlings were transplanted in a semi climate controlled polyhouse of $30 \times 30 \times 6 \mathrm{~m}$ size. Flowering started 3 months after transplanting of seedlings. After observing the visual appearance, fruit were harvested at commercial ripened maturity (Fig. 1), pre-cooled at room temperature. Healthy and uniform fruit were selected for further experiments.
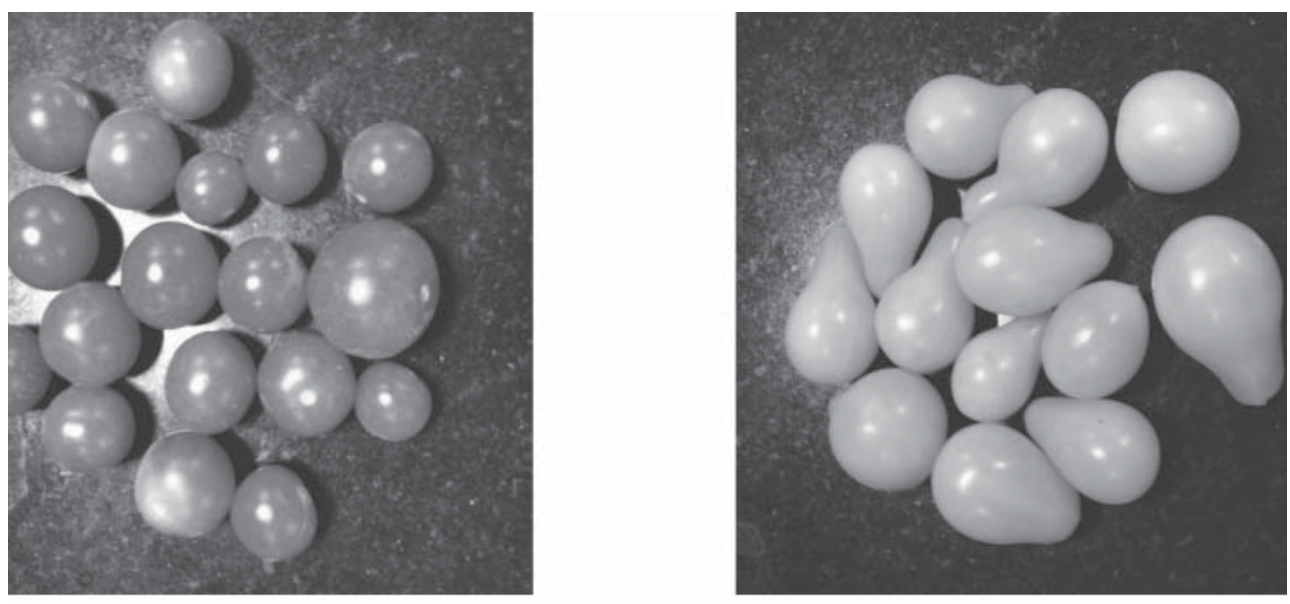

Fig. 1. Pictorial view of (a) Pusa cherry tomato-1 (b) Yellow pear at stage of maturity

\subsection{Chemicals}

Chemicals and reagents of analytical grade used for the study were procured from Merck India, Ltd. 


\subsection{Physical and physiological parameters}

Dry matter (\%) was determined by drying a known weight of the whole tomato reduced into identical pieces in oven at $60 \pm 5^{\circ} \mathrm{C}$ to constant weight. Respiration rate was measured by placing $500 \mathrm{~g}$ of fresh fruit in an airtight container having twist-top lid fitted with a silicone rubber septum at the center of the lid. After $4 \mathrm{~h}$, the headspace gas was sucked through a hypodermic hollow needle and placed in an auto gas analyser (Model: Checkmate $9900 \mathrm{O}_{2} /$ $\mathrm{CO}_{2}$, $\mathrm{PBI}$ Dansensor, Denmark) and the results were expressed as $\mathrm{ml} \mathrm{CO}_{2} \mathrm{~kg}^{-1} \mathrm{~h}^{-1}$.

\subsection{Biochemical and functional parameters}

Total soluble solids content (\%) of homogenized tomatoes were estimated using Fisher hand refractometer $\left(0-50^{\circ} \mathrm{Brix}\right)$ at $20^{\circ} \mathrm{C}$. Titratable acidity (\%) was estimated by standard titration method with $0.1 \mathrm{~N} \mathrm{NaOH}$ using phenolphthalein indicator. Ascorbic acid $(\mathrm{mg} / 100 \mathrm{~g})$ was estimated by AOAC (2000) method. Lycopene from homogenized tomato extracts was estimated as reported by BRANDT and co-workers (2003). Total carotenoids ( $\mathrm{mg} / 100 \mathrm{~g}$ of fruit weight) were determined by method described by SHARPLESS and co-workers (1999). Total phenolic content (mg GAE/100 g) was determined by method of SingLETON and Rossi (1965). Antioxidant capacity ( $\mu$ mol Trolox equiv./g) was determined by "CUPRAC" method, as standardized by APAK and co-workers (2008).

\subsection{Statistical analysis}

The experiment was conducted in a completely randomized design, taking thirty fruit of each cultivar with three replicates. Results were analyzed using analysis of variance, and the mean values were compared by Duncan's multiple range test (DMRT). Two-way analysis of variance was performed using PROC GLM of SAS 9.3 software (SAS Institute, Cary, NC, USA), and significant effects $(\mathrm{P}<0.05)$ were noted. Further, a significant difference amongst the means was determined by Tukey's HSD test. Principal component analysis (PCA) was carried out to find the linear relationship among the different variables to identify the trait that causes maximum proportion of variability in the cultivars.

\section{Results and discussion}

\subsection{Dry matter}

The highest dry matter content was found in Cherry tomato hybrid no.1 $(7.66 \%)$ followed by Pusa cherry tomato-1 (7.43\%), while the lowest $(5.47 \%)$ content was found in Wild Texas (Table 1). The results substantiated that Cherry tomato hybrid no. 1 is having better processing characteristics owing to its higher dry matter and soluble solids contents. MALUNDO and coworkers (1995) also reported that TSS is the main component of dry matter. The other possibility of high dry matter content could be linked with higher fruit firmness, total sugars and soluble solids contents. The observed results were in agreement with those reported by RADZEvicius and co-workers (2016), where the dry matter and soluble solids contents of tomatoes ranged from 5.645 to $7.670 \%$ and 3.98 to $5.25 \%$, respectively. ABOAGYe-NUAMAH and co-workers (2018) reported significant variation in dry matter contents of the six varieties of tomatoes cultivated in Brong Ahafo region of Ghana. 


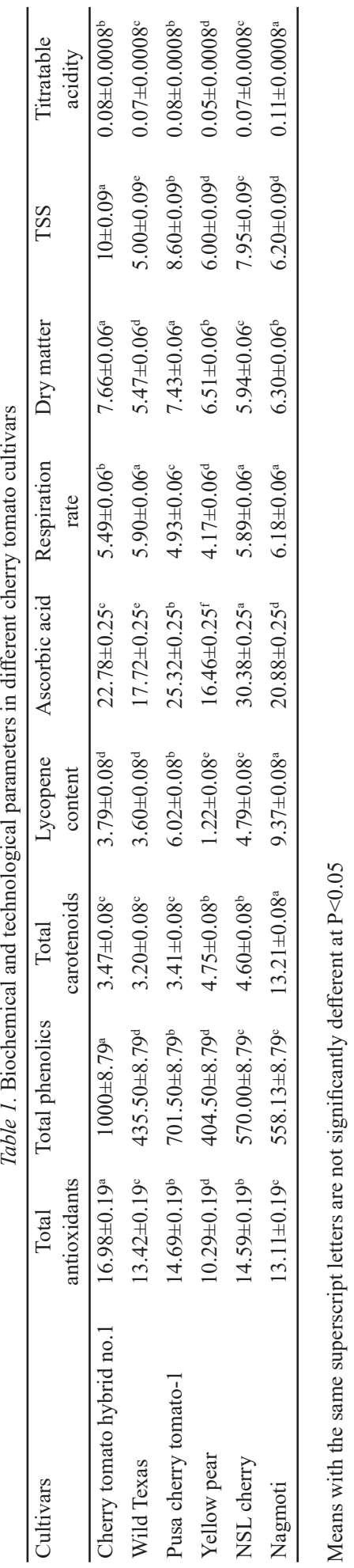




\subsection{Respiration rate}

Table 1 shows that $\mathrm{cv}$. Nagmoti had higher respiration rate $\left(6.18 \mathrm{ml} \mathrm{CO}_{2} \mathrm{~kg}^{-1} \mathrm{~h}^{-1}\right)$ followed by Wild Texas $\left(5.90 \mathrm{ml} \mathrm{CO}_{2} \mathrm{~kg}^{-1} \mathrm{~h}^{-1}\right)$, while Yellow pear had the lowest value $\left(4.17 \mathrm{ml} \mathrm{CO}_{2}\right.$ $\mathrm{kg}^{-1} \mathrm{~h}^{-1}$ ). Reduction in respiration rate could be attributed to the higher firmness of fresh cherry fruit due to lower activity of cell wall degrading enzymes (YAMAN \& BAYOINDIRLI, 2002). The lower rate of respiration and lower $\mathrm{pH}$ values positively correlated with each other. The higher metabolic rate of fresh tomato could be a cause for the faster rate of reduction of titratable acidity and increased $\mathrm{pH}$ values (TIGIST et al., 2013).

\subsection{Total soluble solids}

Cherry tomato hybrid no.1 showed highest TSS (10.0 ${ }^{\circ}$ Brix) followed by Pusa cherry tomato-1 $\left(8.60^{\circ}\right.$ Brix), while the lowest value was obtained in Wild Texas (5.0 ${ }^{\circ}$ Brix) (Table 1). This variation in TSS content was mainly due to the presence of higher dry matter content as also substantiated by MALUNDO and co-workers (1995). The TSS of different cherry tomato cultivars ranged from 5.83 to $9.27{ }^{\circ}$ Brix (CsAmbaLiK et al., 2014) and 4.7 to $8.6^{\circ}$ Brix, respectively (COYAGO-CRUZ et al., 2018).

\subsection{Titratable acidity}

Highest titratable acidity was found in Nagmoti cultivar $(0.114 \%)$ followed by Cherry tomato hybrid no.1 $(0.08 \%)$, while the lowest $(0.05 \%)$ value was found in Yellow pear cultivar (Table 1). GEORGE and co-workers (2004) reported the range of titratable acidity $(0.256$ to $0.704 \%)$ in tomato genotypes. TIGIST and co-workers (2013) reported variation in titratable acidity from 0.748 (cv. Melkasalsa) to 0.889 (cv. Marglobe Improved) in different tomato cultivars.

\subsection{Ascorbic acid (AA)}

NSL cherry cultivar had the highest ascorbic acid content $(30.38 \mathrm{mg} / 100 \mathrm{~g})$ followed by Pusa cherry tomato-1 $(25.32 \mathrm{mg} / 100 \mathrm{~g})$, while lower value was observed in Yellow pear (16.46 $\mathrm{mg} / 100 \mathrm{~g}$ ) showing about 1.85-fold variation (Table 1). GETINET and co-workers (2008) reported the AA content in the range of 11.2 to $25 \mathrm{mg} / 100 \mathrm{~g}$ for the selected tomato cultivars. Similarly, CsambaLIK and co-workers (2014) reported AA content of six different genotypes of cherry tomatoes ranging from 8.3 to $16.7 \mathrm{mg} / 100 \mathrm{~g}$.

\subsection{Total antioxidant capacity}

Among the different cherry tomato cultivars, the highest antioxidant capacity $(16.98 \mu \mathrm{mol}$ Trolox equiv./g) was recorded in Cherry tomato hybrid no.1, followed by Pusa cherry tomato-1 (14.69 $\mu \mathrm{mol}$ Trolox equiv./g), while the lowest antioxidant activity was in NSL cherry $(10.29 \mu \mathrm{mol}$ Trolox equiv./g) (Table 1). The reason behind the higher antioxidant capacity in Cherry tomato hybrid no.1 was higher phenolic content as proved in present study. Growing season, area of cultivation and cultivars also have influence on bioactive compounds of cherry and pigmented tomato fruit (LENUCCI et al., 2006). 


\subsection{Total phenolic content}

In the study, total phenolic content ranged from $404.50 \mu \mathrm{g} \mathrm{GAE} / \mathrm{g}$ FW (cv. Yellow pear) to $1000 \mu \mathrm{g} \mathrm{GAE} / \mathrm{g} \mathrm{FW}$ (cv. Cherry tomato hybrid no.1), depicting 2.47-fold variation (Table 1). Variation in phenolic content was due to the difference in metabolic activity, which leads to consumption of phenols by the fruit tissues immediately after harvest. Loss of cell wall integrity and varietal characteristics may sometimes result in lower levels of phenols. This variation might also be due to a difference in the genotypic background of cherry tomato cultivars (CsambaLiK et al., 2014). The presence of quantitative trait loci for phenylalanine, which is the substrate for phenylalanine ammonia-lyase for polyphenol biosynthesis, in the cultivars/genotypes also affected phenols (SCHAUER et al., 2006).

\subsection{Total carotenoid and lycopene content}

Results depicted that the highest total carotenoid content $(13.21 \mathrm{mg} / 100 \mathrm{~g})$ was found in $\mathrm{cv}$. Nagmoti, while the lowest carotenoid content $(3.20 \mathrm{mg} / 100 \mathrm{~g})$ was found in cv. Wild Texas. Nagmoti cultivar showed the highest lycopene content $(9.37 \mathrm{mg} / 100 \mathrm{~g})$ followed by Pusa cherry tomato-1 (6.02), while the lowest value $(1.22 \mathrm{mg} / 100 \mathrm{~g})$ was found in $\mathrm{cv}$. Yellow pear (Table 1). Genetic factor is one of the most important factors for lycopene content, but the effect of environmental conditions was also reported by GiUnTINI and co-workers (2005). Also, CsambaliK and co-workers (2014) reported lycopene $(6.2-14.9 \mathrm{mg} / 100 \mathrm{~g})$ and $\beta$-carotene $(0.52-1.03 \mathrm{mg} / 100 \mathrm{~g})$ contents of six cultivars and landraces.

\subsection{Coefficient correlation between bioactive compounds and antioxidant activity}

Table 2 shows significant positive correlation $\left(\mathrm{R}^{2}=0.877\right)$ between total antioxidant activity (CUPRAC) and total phenolic content. Similarly, total carotenoids were found positively correlated with lycopene content $\left(\mathrm{R}^{2}=0.759\right)$. For lycopene content and TA, significant positive correlation $\left(\mathrm{R}^{2}=0.946\right)$ was observed. In addition, positive correlation among dry matter and total phenolics values $\left(\mathrm{R}^{2}=0.808\right)$; and among dry matter and TSS $\left(\mathrm{R}^{2}=0.823\right)$ values was observed. ОвоULBIGA and co-workers (2018) reported strong positive correlation between lycopene and $\beta$-carotene content of tomato cultivars.

\subsection{Principal component analysis of cherry tomato cultivars}

The observed value of PCA analysis showed that three out of nine principal components have Eigen value higher than 0.7 , which contributes to $91.74 \%$ of total variation (Table 3). In Figure 2, the variables are related to one another if they are close to each other in the same geometric plane of biplot and higher distance from variables are negatively correlated. Total antioxidants, ascorbic acid and total phenolics are positively correlated to PC1 but negatively correlated to PC2. PCA has been applied by several authors in order to establish the relationship between various quality parameters as well as sensory attributes of cherry tomatoes (Csambalik et al., 2014; Coyago-CruZ et al., 2018). 

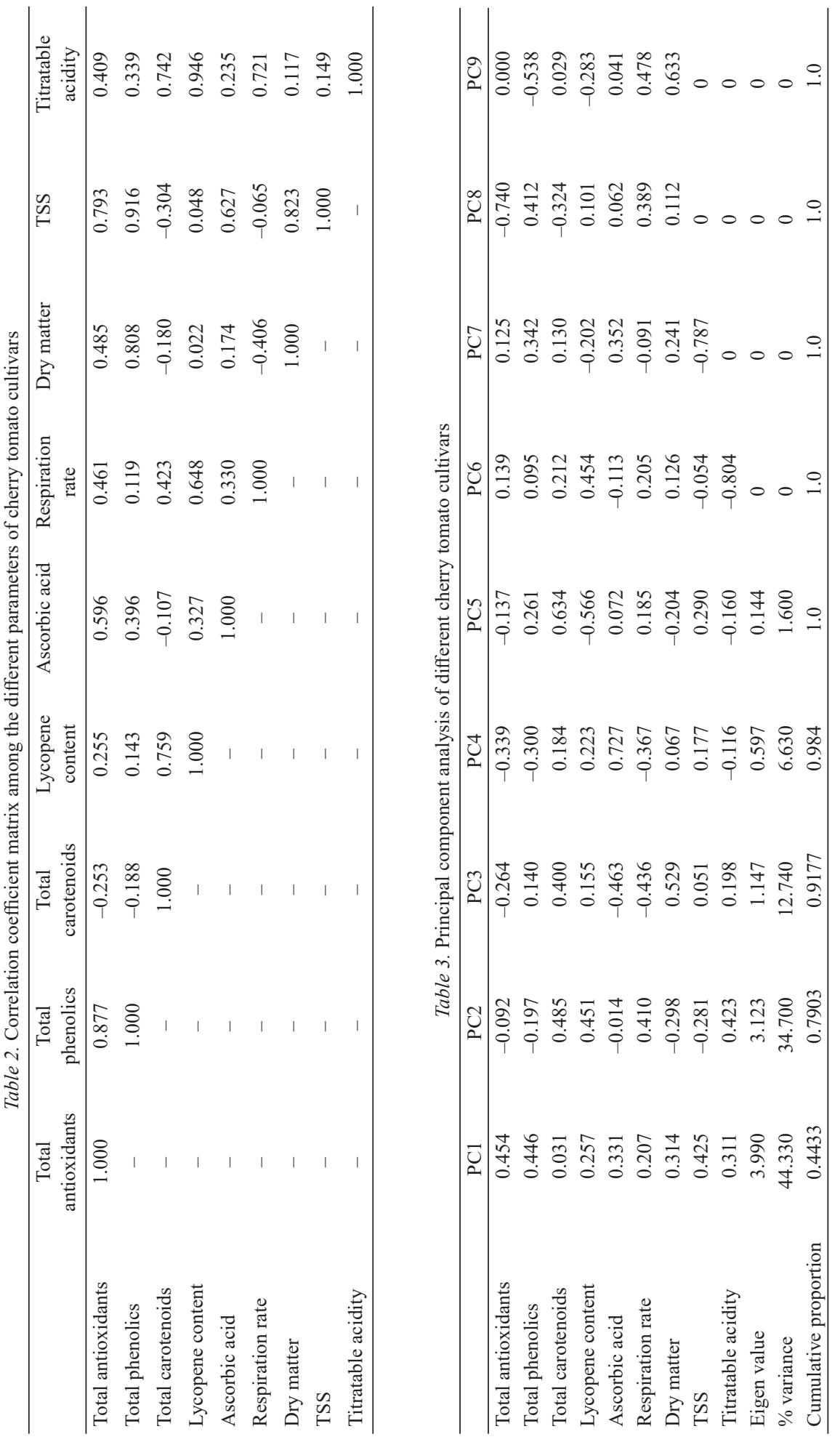


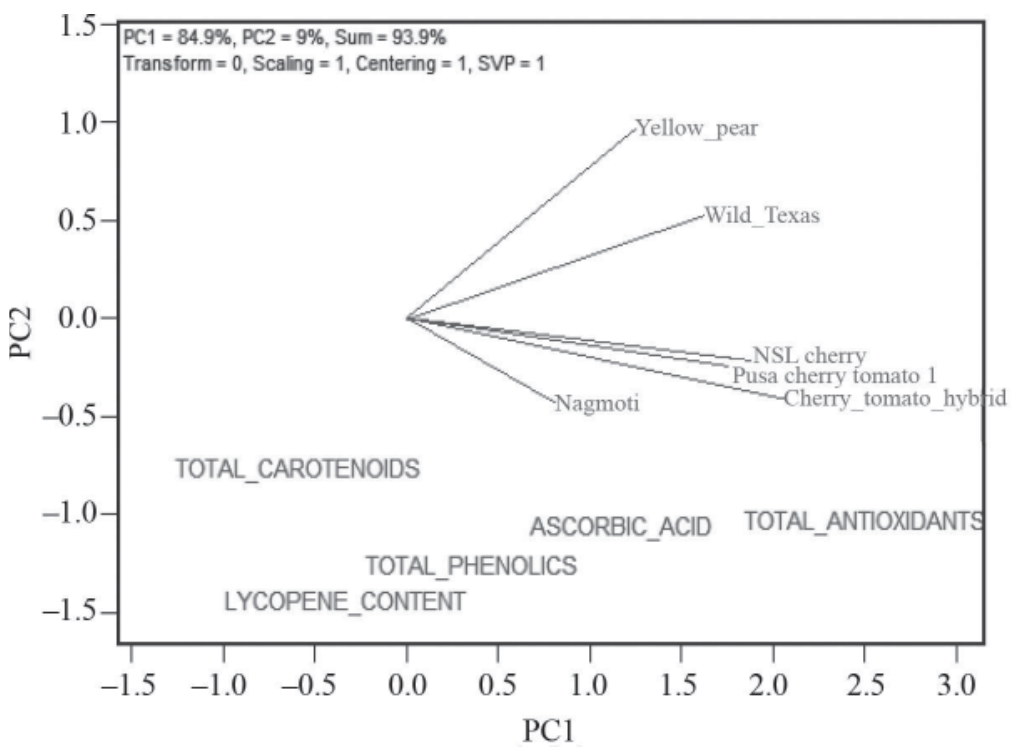

Fig. 2. Graphical representation showing the variation of bioactive compounds using principal component analysis

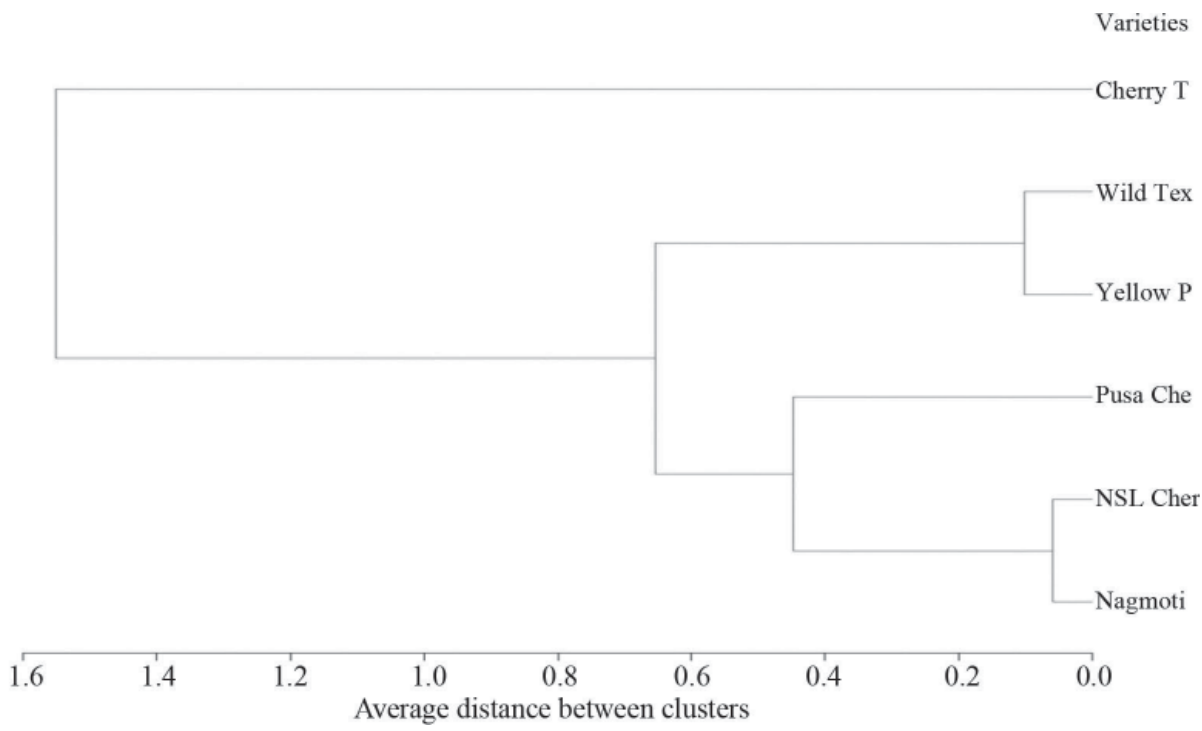

Fig. 3. Hierarchical cluster analysis of different cultivars based on evaluated quality attributes

\subsection{Hierarchical cluster analysis of cherry tomato cultivars}

Cluster analysis was carried out by the method of 'Average Linkage Cluster Analysis' from the average distances between the bioactive parameters. In the present study, the scale from 0-1.6 was used to determine the relationship between the different cultivars (Fig. 3). The entire cluster was split into four sub-clusters. The first cluster was divided into two major 
sub-clusters. Cluster-1 has two closely related cultivars namely NSL cherry and Nagmoti with average root means square distance of 0.0591 between them. In cluster-2, Wild Texas and Yellow pear cultivar are closely related with an average distance of 0.118 for all bioactive components. Fourth cluster contained only one cultivar Cherry tomato hybrid no.1, which is almost homogeneous to all other five cultivars with respect to bioactive compounds.

\section{Conclusions}

Significant differences in terms of bioactive compounds and biochemical parameters were observed in the evaluated cultivars. Total antioxidant activity and total phenolic content were highest in Cherry tomato hybrid no.1, however, total carotenoids content was maximum in cv. Nagmoti. The total antioxidant activity had maximum linear correlation with total phenolics content. Principal component analysis validated that significant differences in terms of antioxidant activity, total phenolics, ascorbic acid and total carotenoids contents were observed in the selected six cultivars. Findings of this study can offer an opportunity to use cherry tomato for processing purpose. The evaluated cultivars also have the potential to increase the intake of bioactive compounds through diet, with developing functional food products beside fresh consumption.

The financial support and laboratory facilities provided by ICAR-CIPHET, Ludhiana, and ICAR-IARI, New Delhi are duly acknowledged.

\section{References}

Aboagye-Nuamah, F., Hussein, Y.A. \& Ackun, A. (2018): Biochemical properties of six varieties of tomato from Brong Ahafo region of Ghana as influenced by the ripening condition and drying. AJFAND, 18(1), 1309513109 .

AOAC (2000): Official methods of analysis of AOAC International, 17 $7^{\text {th }}$ ed. USA. Method No. 967.21.

Apak, R., Guclu, K., OzyureK, M. \& Celik, S.E. (2008): Mechanism of antioxidant capacity assays and the CUPRAC (cupric ion reducing antioxidant capacity) assay. Mikrochim Acta., 160, 413-419.

Brandt, S., Lugasi, A., Barna, E., Hovari, J., PeK, Z. \& Helyes, L. (2003): Effects of the growing methods and conditions on the lycopene content of tomato fruits. Acta Alimentaria, 32, 269-278.

Bruno, A., Durante, M., Marrese, P.P., Migoni, D., Laus, M.N., ... \& Lenucci, M.S. (2018): Shades of red: Comparative study on supercritical $\mathrm{CO}_{2}$ extraction of lycopene-rich oleoresins from gac, tomato and watermelon fruits and effect of the $\alpha$-cyclodextrin clathrated extracts on cultured lung adenocarcinoma cells' viability. Ð. Food Compos. Anal., 65, 23-32.

Coyago-Cruz,E.,Corell,M.,Moriana,A.,Hernanz,D.,Benitez-Gonzalez,A.M.,...\&Melendez-Martinez,A.J. (2018): Antioxidants (carotenoids and phenolics) profile of cherry tomatoes as influenced by deficit irrigation, ripening and cluster. Food Chem., 240, 870-884.

Csambalik, L., Diveky-ertsey, A., Pap, Z., Orban, C., Mate, M.S., ... \& \& Sipos, L. (2014): Coherences of instrumental and sensory characteristics: Case study on cherry tomatoes. J. Food Sci., 79(11), C2192-C2202.

George, B., Kaur, C., Khurdiya, D.S. \& Kapoor, H.C. (2004): Antioxidants in tomato (Lycopersium esculentum Mill.) as a function of genotype. Food Chem., 84, 45-51.

Getinet, H., Seyoum, T.W. \& Woldetsadik, K. (2008): The effect of cultivar, maturity stage and storage environment on quality of tomatoes. J. Food Eng., 87(4), 467-478.

Giuntini, D., Graziani, G., Lercari, B., Fogliano, V., Soldatini, G.F. \& Ranieri, A. (2005): Changes in carotenoid and ascorbic acid contents in fruits of different tomato genotypes related to the depletion of UV-B radiation. J. Agr. Food Chem., 53, 3174-3181.

Helyes, L., PeK, Z. \& Lugasi, A. (2008): Function of the variety technological traits and growing conditions on fruit components of tomato (Lycopersicon lycopersicum L. Karsten). Acta Alimentaria, 37, 427-436. 
Ilahy, R., Siddiqui, M.W., Tlili, I., Montefusco, A., Piro, G., Hdider, C. \& Lenucci, M.S. (2018): When color really matters: horticultural performance and functional quality of high-lycopene tomatoes. Crit. Rev. Plant Sci., $37(1), 15-53$.

Ilahy, R., Tlili, I., Siddiqui, M.W., Hdider, C. \& Lenucci, M.S. (2019): Inside and beyond color: Comparative overview of functional quality of tomato and watermelon fruits. Front Plant Sci., 10:769, doi: 10.3389/ fpls.2019.00769.

Lenucci, M.S., Cadinu, D., Taurino, M., Piro, G. \& Dalessandro, G. (2006): Antioxidant composition in cherry and high-pigment tomato cultivars. J. Agr. Food Chem., 54, 2606-2613.

Malundo, M., Shewfelt, R. \& Scott, J. (1995): Flavor quality of fresh tomato (Lycopersicon esculentum Mill.) as affected by sugar and acid levels. Postharvest Biol. Technol., 6, 103-110.

Oboulbiga, E.B., Traore, C.O., Tarpaga, W.V., Parkouda, C., Sawadogo-Lingani, H., ... \& Traore, A.S. (2018): Assessment of the content of $\beta$-carotene, lycopene and total phenolic of 45 varieties of tomatoes (Solanum lycopersicum L.). J. Food Nutr. Sci., 6(3), 82-89.

Radzevicius, A., Viskelis, J., Karkleliene, R., Juskeviciene, D. \& Viskelis, P. (2016): Determination of tomato quality attributes using near infrared spectroscopy and reference analysis. Zemdirbyste, 103(1), 91-98.

Schauer, N., Semel, Y., Roessner, U., Gur, A., Balbo, I., ... \& Fernie, A.R. (2006): Comprehensive metabolic profiling and phenotyping of interspecific introgression lines for tomato improvement. Nat. Biotechnol., 24, $447-454$.

Sharpless, K.A., Arce-Osuna, M., Thomas, J.B. \& Gill, L.M. (1999): Value assignment of retinyl palmitate, tocopherol and carotenoid concentrations in standard reference material 2383 (Baby food composite). J. AOAC Int., 82(2), 288-296.

Singleton, V.L. \& Rossi, J.A. (1965): Colorimetry of total phenolics with phosphomolybdic-phosphotungstic acid reagents. Am. J. Enol. Viticult., 16, 144-158.

Tigist, M., Workneh, T.S. \& Woldetsadik, K. (2013): Effects of variety on the quality of tomato stored under ambient conditions. J. Food Sci. Tech., 50(3), 477-486.

YAman, O. \& Bayoindirli, L. (2002): Effects of an edible coating and cold storage on shelf-life and quality of cherries. LWT-Food Sci. Technol., 35, 46-150. 